\title{
Optimum Seed Rate and Nitrogen Requirement for Broadcast Blackgram (Vigna mungo l.) Grown on Rain-fed Uplands
}

\author{
R.T. Ekanayake, M.A.P.W.K. Malaviarachchi ${ }^{1}$, P.S.G. Upashantha ${ }^{1}$ \\ R.M. Fonseka ${ }^{2 *}$ and R.M. Ranaweera Banda ${ }^{1}$
}

\author{
Postgraduate Institute of Agriculture \\ University of Peradeniya \\ Sri Lanka
}

\begin{abstract}
A field experiment was conducted at the Field Crops Research and Development Institute, Mahailluppllama to identify an optimum seed rate and the respective nitrogen level for broadcast blackgram grown on rainfed uplands during Maha 2009/2010 with the variety MI-1. The study was carried out as a two factor factorial experiment. Six seed rates $(25 \mathrm{~kg} / \mathrm{ha}, 37.5 \mathrm{~kg} / \mathrm{ha}, 50 \mathrm{~kg} / \mathrm{ha}, 62.5 \mathrm{~kg} / \mathrm{ha}, 75 \mathrm{~kg} / \mathrm{ha}, 87.5 \mathrm{~kg} / \mathrm{ha})$ with two rates of nitrogen (30 kg of N/ha, Zero $N$ ) were the two factors tested in the experiment. The results revealed that the plant height, leaf area per plant and canopy diameter did not vary with the seed rate but significantly varied with fertilizer rates. Number of pods per plant, number of seeds per pod and 1000 seed weight did not vary with the seed rate but number of pods per plant and 1000 seed weight varied with the fertilizer level. The maximum yield was recorded at a seed rate of $64 \mathrm{~kg} / \mathrm{ha}$. Economic analysis revealed that the optimum seed rate is 62.5 $\mathrm{kg} / \mathrm{ha}$. The number of plants/ $\mathrm{m}^{2}$ at which maximum yield was obtained was estimated as 93 plants $/ m^{2}$ which is also comparable to this seed rate. As there were no differences observed in yield components except for the number of plants per unit area, the main contributing factor for yield increments with increasing seed rate was the number of plants per unit area. Therefore, it can be concluded that the optimum seed rate for broadcast crop of black gram under rain-fed conditions is $62.5 \mathrm{~kg} / \mathrm{ha}$ when $\mathrm{N}$ is supplied at the rate of $30 \mathrm{~kg} / \mathrm{ha}$.
\end{abstract}

Key words: Blackgram, Nitrogen requirement, Optimum rate seed

\section{INTRODUCTION}

Grain legume cultivation in Sri Lanka is mainly concentrated in the dry $(47.5 \%)$ and intermediate zones (48\%) under rain-fed Chena cultivation and the rest, $5.5 \%$ is in the wet zone homesteads (Kunasingham, 1982). Blackgram is considered as one of the important grain legumes in rain-fed farming systems in the dry and intermediate zones of Sri Lanka. It can be grown under low moisture and fertility conditions. At present, blackgram is successfully cultivated in the districts of Anuradhapura, Vavuniya, Kurunegala, Puttlam, Killinochchi, Mulativu, Batticaloa and Jaffna (Anon, 2009). The seeds are highly nutritious with proteins $(25-26 \%)$, carbohydrates $(60 \%)$, fat $(1.5 \%)$, minerals, amino acids and vitamins. Seeds are used in preparation of many popular dishes in Sri Lanka. It is also one of the most important components in the preparation of famous South Indian dishes such as Dosa, Idli, and Vada.

To whom correspondence should be addressed: ramyamf@pdn.ac.lk Field Crops Research and Development Institute, Mahailluppallama

Department of Crop Science, Faculty of Agriculture, University of Peradeniya, Peradeniya 
The cultivated extents and production of blackgram in Sri Lanka varies from year to year with an increasing trend (Anon, 2005; Anon, 2006; Anon, 2007; Anon 2008 and Anon 2009). About $80 \%$ of blackgram crop is cultivated during the Maha season as a rain-fed upland crop and the rest is grown in yala in paddy fields with supplementary irrigation. For Maha cultivation, blackgram is planted in the middle of the season to escape the heavy rains that prevail at the tail end of the season. The seed rate for blackgram is $30 \mathrm{~kg} / \mathrm{ha}$ when planted in rows at the spacing of $40 \mathrm{~cm} \times 10 \mathrm{~cm}$ as per the recommendations of the Department of Agriculture (DOA). At planting, 2 seeds/ hill are placed and after 10-12 days weaker plants are thinned out (Anon, 1990). However, the farmers do not follow the above recommendations for crop establishment mainly due to labor shortage as labor demand for rice cultivation is higher during the same period. Therefore, farmers usually broadcast seeds on the harrowed land at different seed rates since there is no recommended package of practices for broadcast blackgram. Optimum plant density is a primary requirement for a better crop growth in order to minimize intra-species competition (Whaley et al., 1981). Therefore, the objective of this study was to identify an optimum seed rate and the respective nitrogen level for broadcast blackgram grown on rain-fed uplands in the dry zone.

\section{MATERIALS AND METHODS}

This study was conducted as a rain-fed field experiment at Field Crops Research and Development Institute, Mahailluppallama, located in the agro-ecological zone $\mathrm{DL}_{1 \mathrm{~b}}$ where the average annual rain fall is $>900 \mathrm{~mm}$ and the elevation is $117.3 \mathrm{~m}$ above mean sea level. Basic soil characteristics of the site were pH (6.0); EC (0.04); Nitrogen (0.02\%); phosphorous (14 ppm); potassium (180 ppm) and OM $(0.89 \%)$. The study was carried out as a two factor factorial experiment. The design used was a Randomized Complete Block Design (RCBD) with 3 replicates. Plot size was $15 \mathrm{~m}^{2}(5 \mathrm{~m} \mathrm{x} 3 \mathrm{~m})$. The two factors were the seed rate and the fertilizer rate. Six seed rates (viz. $25 \mathrm{~kg} / \mathrm{ha}, 37.5 \mathrm{~kg} / \mathrm{ha}, 50 \mathrm{~kg} / \mathrm{ha}, 62.5$ $\mathrm{kg} / \mathrm{ha}, 75 \mathrm{~kg} / \mathrm{ha}$ and $87.5 \mathrm{~kg} / \mathrm{ha}$ ) with two levels of nitrogen (viz: DOA recommendation and Zero N) were tested in the experiment using the blackgram variety MI-1. The seeds were broadcast and covered with a thin soil layer.

Nitrogen was applied as urea at the rate of $30 \mathrm{~kg} / \mathrm{ha}$ in two split applications (viz. $16 \mathrm{~kg} / \mathrm{ha}$ as the basal dressing and $14 \mathrm{~kg} / \mathrm{ha}$ as the top dressing at the time of flowering) only for the $\mathrm{N}$ treatment. Triple super phosphate and Muriate of potash were applied at the rates of 100 $\mathrm{kg} / \mathrm{ha}$ and $50 \mathrm{~kg} / \mathrm{ha}$ respectively as a basal dressing for both $\mathrm{N}$ treatment levels. Number of plants per square meter was counted at 4 weeks after seeding (WAS). Weed count and weed dry weights were measured at 2 WAS and at flowering of black gram. Plant height, canopy diameter and leaf area were measured at flowering. All yield components namely, number of pods per plant, number of seeds per pod, 1000 seed weight and total seed weight were measured at harvesting. Data were analyzed using Analysis of Variance (ANOVA) procedure in the Statistical Analysis System (SAS). An economic analysis was performed following the partial budget technique (CIMMYT, 1988) in order to determine the most economical seed rate for broadcast blackgram under rain-fed farming.

\section{RESULTS AND DISCUSSION}

Monthly variation of rainfall during 2009/2010 Maha season is given in Fig. 1. The highest rainfall occurred in November at the end of which the crop was planted. Planting at this time helped better germination of seeds and proper vegetative growth. Harvesting was done at the 
end of January where the least rainfall was recorded as the harvesting stage of legumes should coincide with the driest part of the growing season.

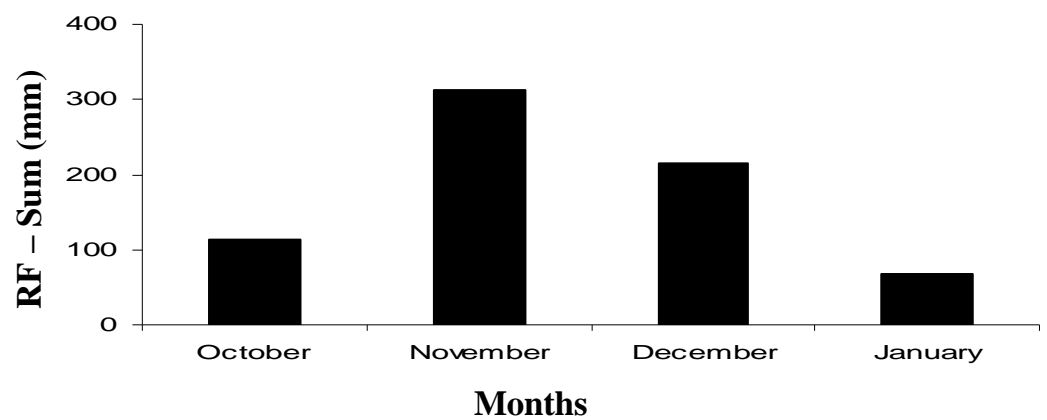

Fig. 1. Average monthly rainfall during 2009/2010 Maha season

Since no interactions were found between the two factors tested, only the main effects are discussed herein. There were no significant differences between the different seed rates $(\mathrm{P}>0.05)$ for all the growth parameters measured (plant height, leaf area and canopy diameter) (Table 1). However, they were significantly different with the different nitrogen fertilizer rates (Table 2). The DOA recommended $\mathrm{N}$ rate showed $40 \%, 45 \%$ and $23 \%$ increases in plant height, leaf area and canopy diameter, respectively in comparison to zero $\mathrm{N}$ application. It has been reported by Koren and kov (1983) that the use of nitrogen fertilizers considerably increased the yield of pulses.

Table 1. Plant height, leaf area and canopy diameter as affected by seed rate

\begin{tabular}{llcc}
\hline $\begin{array}{l}\text { Seed rate } \\
(\mathbf{k g} / \mathbf{h a})\end{array}$ & $\begin{array}{c}\text { Plant height } \\
(\mathbf{c m})\end{array}$ & $\begin{array}{c}\text { Leaf Area } \\
\left(\mathbf{c m}^{\mathbf{2}}\right)\end{array}$ & $\begin{array}{c}\text { Canopy Diameter } \\
(\mathbf{c m})\end{array}$ \\
\hline 25 & $24.34^{\mathrm{a}}$ & $415.44^{\mathrm{ab}}$ & $27.04^{\mathrm{a}}$ \\
37.5 & $26.83^{\mathrm{a}}$ & $438.85^{\mathrm{a}}$ & $24.77^{\mathrm{a}}$ \\
50 & $26.95^{\mathrm{a}}$ & $316.34^{\mathrm{b}}$ & $24.97^{\mathrm{a}}$ \\
62.5 & $27.25^{\mathrm{a}}$ & $347.58^{\mathrm{ab}}$ & $26.55^{\mathrm{a}}$ \\
75 & $29.45^{\mathrm{a}}$ & $448.02^{\mathrm{a}}$ & $24.93^{\mathrm{a}}$ \\
87.5 & $28.43^{\mathrm{a}}$ & $336.68^{\mathrm{ab}}$ & $25.03^{\mathrm{a}}$ \\
$\operatorname{Pr}>\mathrm{F}$ & 0.359 & 0.5303 & 0.0573 \\
$\mathrm{CV}(\%)$ & 14.45 & 22.75 & 10.24 \\
\hline
\end{tabular}

* Values in a column followed by the same letter are not significantly different $(\mathrm{p}=0.05)$

Table 2. Plant height, leaf area and canopy diameter as affected by Nitrogen fertilizer rate

\begin{tabular}{llll}
\hline N fertilizer rate & \multicolumn{1}{c}{$\begin{array}{c}\text { Plant height } \\
(\mathbf{c m})\end{array}$} & $\begin{array}{c}\text { Leaf area } \\
(\mathbf{c m})\end{array}$ & $\begin{array}{c}\text { Canopy diameter } \\
(\mathbf{c m})\end{array}$ \\
\hline DOA N fertilizer & $31.45^{\mathrm{a}^{*}}$ & $453.89^{\mathrm{a}}$ & $28.17^{\mathrm{a}}$ \\
recommendation & $22.97^{\mathrm{b}}$ & $313.74^{\mathrm{b}}$ & $22.93^{\mathrm{b}}$ \\
Zero N fertilizer & 0.0001 & 0.0001 & 0.0001 \\
Pr>F & 14.45 & 22.75 & 10.24 \\
CV\% & &
\end{tabular}

* Values followed by the same letter are not significantly different $(\mathrm{p}=0.05)$ 
No variations were observed in yield components such as number of pods/plant, number of seeds/pod and 1000 seed weight with the different seed rates $(\mathrm{P}>0.05)$ (Table 3) whereas pods/plant and 1000 seed weight differed significantly with different nitrogen fertilizer rates (Table 4). Compared to zero N, DOA recommended $\mathrm{N}$ rate showed a $65 \%$ higher number of pods/plant and $17 \%$ higher 1000 seed weight. Increase in yield components in blackgram due to application of Nitrogen at the rate of $30 \mathrm{~kg} / \mathrm{ha}$ was also observed by Tandon (1993).

Table 3. Pods/plant, seeds/pod and 1000 seed weight as affected by seed rate

\begin{tabular}{llll}
\hline $\begin{array}{l}\text { Seed rate } \\
(\mathbf{k g} / \mathbf{h a})\end{array}$ & Pods/plant & Seeds/pod & 1000 Seed weight \\
\hline 25 & $11^{\mathrm{a}}$ & $7^{\mathrm{a}}$ & $139.1^{\mathrm{a}}$ \\
37.5 & $11^{\mathrm{a}}$ & $7^{\mathrm{a}}$ & $137.6^{\mathrm{a}}$ \\
50 & $9^{\mathrm{a}}$ & $7^{\mathrm{a}}$ & $138.2^{\mathrm{a}}$ \\
62.5 & $10^{\mathrm{a}}$ & $7^{\mathrm{a}}$ & $145.8^{\mathrm{a}}$ \\
75 & $9^{\mathrm{a}}$ & $7^{\mathrm{a}}$ & $136.7^{\mathrm{a}}$ \\
87.5 & $8^{\mathrm{a}}$ & $7^{\mathrm{a}}$ & $142.8^{\mathrm{a}}$ \\
$\operatorname{Pr}>\mathrm{F}$ & 0.237 & 0.526 & 0.994 \\
$\mathrm{CV}(\%)$ & 22.9 & 6.4 & 21.2 \\
\hline
\end{tabular}

* Values followed by the same letter are not significantly different $(\mathrm{p}=0.05)$

Table 4. Pods/plant, seeds/pod and 1000 seed weight as affected by nitrogen fertilizer rate

\begin{tabular}{lccc}
\hline Nitrogen fertilizer rate & Pods/plant & Seeds/pod & 1000 Seed weight \\
\hline $\begin{array}{l}\text { DOA N fertilizer } \\
\text { recommendation }\end{array}$ & $12.10^{\mathrm{a}^{*}}$ & $7.2^{\mathrm{a}}$ & $151.04^{\mathrm{a}}$ \\
Zero N fertilizer & $7.34^{\mathrm{b}}$ & $7.0^{\mathrm{a}}$ & $129.04^{\mathrm{b}}$ \\
Pr>F & 0.001 & 0.235 & 0.0368 \\
CV\% & 22.9 & 6.4 & 21.20 \\
\hline
\end{tabular}

*Values followed by the same letter are not significantly different, following DMRT at $\mathrm{p}=0.05$

As shown in Fig. 2, the maximum yield was recorded at the $64 \mathrm{~kg} / \mathrm{ha}$ seed rate. This was obtained by equalizing the first derivative of the curve to zero (Fig. 2 and Formula 1). Following the same procedure, the number of plants per square meter at which maximum yield could be obtained was 93 (Fig. 3 and formula 2). It is evident from Table 5 that this plant density could be obtained from $50-75 \mathrm{~kg} / \mathrm{ha}$ seed rates. However, the seed requirement for row seeding is $25-30 \mathrm{~kg} / \mathrm{ha}$ (Anon, 1990). Thus, the seed rate was doubled when it was broadcast. This finding is in agreement with Whaley et al. (1981) who reported that broadcast crops required double the seed rates than that of row seeding. The respective plant density for blackgram, when the crop is row seeded as per the DOA recommendation is 25 plants $/ \mathrm{m}^{2}$ (Anon, 1990). In the present experiment, the plant density where the maximum yield was given (93 plants $/ \mathrm{m}^{2}$ ) was much higher when compared to the rate recommended for row seeding ( 25 plants $/ \mathrm{m}^{2}$ ). That may have created negative impacts on comparatively lower yields in broadcast blackgram due to intra-species competition. 


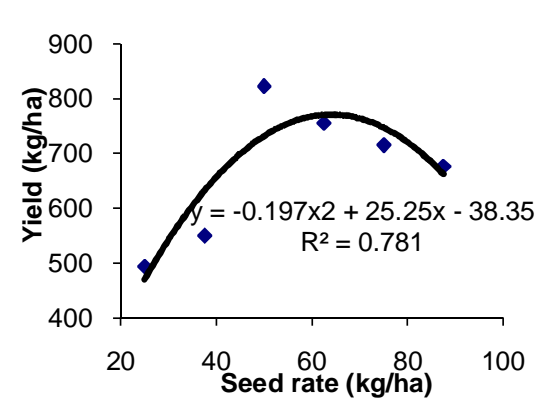

Fig. 2. Yield as affected by seed rate

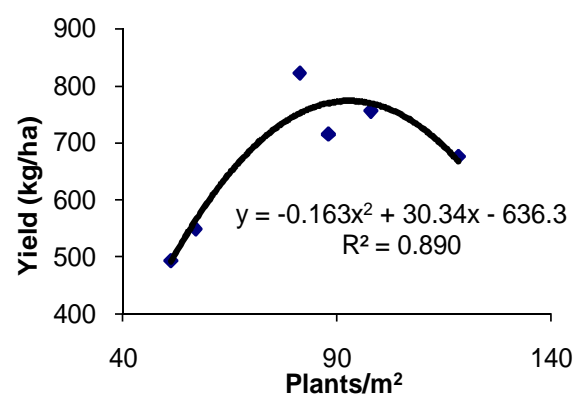

Fig. 3. Yield as affected by plants $/ \mathrm{m}^{2}$

$G Y=-0.197 R^{2}+25.25 R-38.36$ Formula (1)

When GY is maximum

$0=\mathrm{dGY} / \mathrm{dR}=0.394 \mathrm{R}+25.25$

$\mathrm{R}=64 \mathrm{~kg} / \mathrm{ha}$

$G Y=-0.163 D^{2}+30.34 D-636.3$ Formula (2)

When GY is maximum

$0=\mathrm{dGY} / \mathrm{dD}=-0.326 \mathrm{D}+30.34$

$\mathrm{D}=93$ plants $/ \mathrm{m}^{2}$

Where GY $=$ Grain yield $; \mathrm{R}=$ Seed Rate and $\mathrm{D}=$ Number of plants $/ \mathrm{m}^{2}$

Table 5. Plant number at 4 weeks after planting as affected by the seed rate

\begin{tabular}{|c|c|}
\hline Seed rate (kg/ha) & Plants/m ${ }^{2}$ \\
\hline 25 & $51.32^{\mathrm{c}^{*}}$ \\
\hline 37.5 & $57.0^{\mathrm{c}}$ \\
\hline 50 & $81.32^{\mathrm{b}}$ \\
\hline 62.5 & $98.0^{\mathrm{b}}$ \\
\hline 75 & $88.00^{\mathrm{b}}$ \\
\hline 87.5 & $118.32^{\mathrm{a}}$ \\
\hline $\operatorname{Pr}>\mathrm{F}$ & 0.0001 \\
\hline CV\% & 17.9 \\
\hline
\end{tabular}

*Values followed by the same letter are not significantly different $(\mathrm{p}=0.05)$

Yields were remarkably higher (34\%) at the DOA recommended $\mathrm{N}$ fertilizer rate than zero $\mathrm{N}$ application. A twenty six percent increase of the yield was observed by Rajendran (1974) and Dhage et al. (1984) with $30 \mathrm{~kg} / \mathrm{ha} \mathrm{N}$ fertilizer application.

Table 6. Yield as affected by fertilizer rate

\begin{tabular}{lc}
\hline Nitrogen fertilizer rate & Yield (kg/ha) \\
\hline DOA N fertilizer recommendation & $766.3^{\mathrm{a}}$ \\
Zero N fertilizer & $570.2^{\mathrm{b}}$ \\
Pr>F & 0.0199 \\
CV\% & 13.96 \\
\hline
\end{tabular}


However, it is not reasonable to draw conclusions based only upon the biological outputs since the cost of production varies as the seed rate and fertilizer rate increases and therefore an economic analysis was also performed to find out the optimum seed rate. Accordingly, the maximum profit (Rs. 52,000.00) was obtained at $62.5 \mathrm{~kg} /$ ha seed rate (Table 7). This is close to the seed rate where the maximum yield was realized.

Table 7. Partial budget analysis for different seed rates

\begin{tabular}{|c|c|c|c|c|c|c|}
\hline Seed rate $(\mathrm{kg} / \mathrm{ha})$ & 25 & 37.5 & 50 & 62.5 & 75 & 87.5 \\
\hline${ }^{\mathrm{T}}$ Yield $(\mathrm{kg} / \mathrm{ha})$ & 493 & 549 & 822 & 735 & 714 & 676 \\
\hline${ }^{2}$ Estimated Yield (kg/ha) & 470 & 634 & 732 & 770 & 747 & 663 \\
\hline $\begin{array}{l}{ }^{3} \text { Estimated Gross income } \\
\text { (Rs.) }\end{array}$ & 47000 & 63400 & 73200 & 77000 & 74700 & 66300 \\
\hline Seed cost (Rs.) & 2500.00 & 3750.00 & 5000.00 & 6250.00 & 7500.00 & 8750.00 \\
\hline Fertilizer cost (Rs.) & 18750.00 & 18750.00 & 18750.00 & 18750.00 & 18750.00 & 18750.00 \\
\hline Profit (Rs.) & 25750 & 40900 & 49450 & 52000 & 48450 & 38800 \\
\hline
\end{tabular}

${ }^{1}$ Actual yield averaged over fertilizer levels

${ }^{2}$ Based on the equation

${ }^{3}$ Selling Price - Rs. 100.00/kg

\section{CONCLUSION}

The optimum seed rate and $\mathrm{N}$ level for broadcast crop of black gram under rain-fed conditions of this study were $62.5 \mathrm{~kg} / \mathrm{ha}$ and $30 \mathrm{~kg} / \mathrm{ha}$, respectively.

\section{ACKNOWLEDGEMENT}

The support given by all the members of the divisions of Agronomy and Soil Chemistry and Ms. S.S. Paththinige in the Field Crops Research and Development Institute, Mahailluppallama are greatly appreciated.

\section{REFERENCES}

Anonymous (2009). AgStat. The Pocket book of agriculture statistics. Socio Economic and Planning Centre, Department of Agriculture, Peradeniya, Sri Lanka. pp.16-18.

Anonymous (2008). AgStat. The Pocket book of agriculture statistics. Socio Economic and Planning Centre, Department of Agriculture, Peradeniya, Sri Lanka. pp.16-17.

Anonymous (2007). AgStat. The Pocket book of agriculture statistics. Socio Economic and Planning Centre, Department of Agriculture, Peradeniya, Sri Lanka. pp.16-17.

Anonymous (2006). AgStat. The Pocket book of agriculture statistics. Socio Economic and Planning Centre, Department of Agriculture, Peradeniya, Sri Lanka. pp.16-17.

Anonymous (2005). AgStat. The Pocket book of agriculture statistics. Socio Economic and Planning Centre, Department of Agriculture, Peradeniya, Sri Lanka. P 6. 
Anonymous (1990). Techno-guide, Department of Agriculture, Peradeniya, Sri Lanka, pp.19-22.

CIMMYT (1988). Agronomy Data to Farmer Recommendation. An Economic Training Manual. Completely revised edition. Mexico. DF. pp.20-29

Dhage, A.R., Patil, N.D. and Kadam, S.S (1984). Effects of N and P fertilization on yield and composition of black gram seeds. Plant and Soil. 81, 441-444.

Koren'kov, D.A. (1983). Nitrogen Fertilizers. Oxonian Press, New Delhi, India. pp.72-97.

Kunasingham, A.S. (1982). Grain Legume Production in Asia. Asian productivity organization, Tokyo. pp.138-141.

Rajendran,K. (1984).The availability of soil nutrients during the growth phase of Blackgram. Madras Agric.J. 61, 782-784.

Tandon,H.L.S. (1993). Fertilizer Management in Food Crops. Fertilizer Development and Consultation Organization, New Delhi, India. pp.114-132.

Whaley,R., Roy,S.K. And Badaruddin,M. (1981). Response of mungbean and black gram to broadcast and line-sowing at different plant densities and spacings. Agronomy Research report. Bangladesh Agricultural Research Institute, Bangladesh. pp.1-8. 